\title{
Spatial Dynamics of Air Pollution in Tangerang City, Jabodetabek Metropolitan Area
}

\author{
Muhardiyan Erawan ${ }^{1}$, Mahawan Karuniasa ${ }^{2}$ \\ \{muhardiyan.erawan81@ui.ac.id', mahawancac@yahoo.com²\}
}

Universitas Indonesia, Indonesia ${ }^{1,2}$

\begin{abstract}
Air pollution is the most common problem in urban areas. Growth and population movements are key issues in urban areas that trigger an increase in the number of motor vehicles, especially in the metropolitan area. This condition leads to high and widespread areas affected by air pollution each year. This research aims to illustrate the possibility of distribution patterns and the dynamics of air pollution in urban areas of Tangerang city. The parameters used in this research are carbon monoxide (CO). To illustrate the distribution pattern, the Geographical Information System method was used. The results of this research show that the areas affected by air pollution are spreading annually. Based on the findings of this study, the average CO concentration exceeds the quality standards in 2034. This can be considered by the people and governments to keep urban areas sustainable.
\end{abstract}

Keywords: Air Pollution, Geographical Information System, Metropolitan, Spatial Dynamics, Urban.

\section{Introduction}

Air pollution is one of the main problems in urban areas, especially in the metropolitan area. The results of the WHO research show that ambient air pollution increased by about $8 \%$ between 2008 and 2013 [1]. Air pollution increased in line with the development of regional status to becomes increasingly urban, even as much as the metropolitan area [2]. Urban air pollution has worsened as population increases, vehicle and energy usage, and industrial growth [3]. These conditions can reduce air quality and are harmful to human health. For example, the death rate in the Seoul Metropolitan area resulting from air pollution reaches approximately $15.9 \%$ of the total mortality in 2010 [4]; Quetta is one of the most polluted cities in Pakistan and has been affected by the high level of premature death of children in 2008 [5]; In the Twin Cities metropolitan area in 2008, air pollution resulted in approximately $2-5 \%$ of emergency handling in hospitals due to symptoms of respiratory and cardiovascular disorders, and about 6-13\% culminated in death [6].

Air quality monitoring should be done to prevent such incidents that could harm human health. Indonesian government regulations require each regional head to perform air monitoring at least once a year [7]. However, measurements by regulation and/or method as such are insufficient, as it relies heavily on the precision level of measuring instruments and ignores the air spatial variability [8]. Therefore, research with spatial basis with several scenarios and spatial patterns is indispensable. 
This paper presents the results of the review of some forms of spatial patterns based on the data point location monitoring of air quality over the last few years. Carbon monoxide (CO) is chosen as the parameter used to represent the condition of air quality in this research area, Tangerang City. The study aims to know the spatial patterns of air pollution in the future based on temporal values that have occurred over the past few years. The combination of statistical methods and computerized Geographic Information System is used to study the change of spatial patterns temporally. This research is expected to assist the Government in determining the policy on controlling air pollution in the area of Tangerang city. In addition, this research is expected to trigger other researchers to improve the methods used to achieve more relevant and significant results.

\section{Research Method}

\subsection{Study Area}

The city of Tangerang is one of regency/citiy in Banten Province, one of the provinces in Indonesia, located at $106^{\circ} 32^{\prime}-106^{\circ} 44^{\prime}$ east longitude and $6^{\circ} 6^{\prime}-6^{\circ} 13^{\prime}$ south latitude. The city is bordered by Tangerang Regency to the north and west, and the city of Jakarta to the east and south. The city of Tangerang consists of 13 sub-districts, namely Ciledug, Larangan, Karang Tengah, Cipondoh, Pinang, Tangerang, Karawaci, Jatiuwung, Cibodas, Periuk, Batuceper, Neglasari, and Benda [Fig. 1]. The city of Tangerang has a total area of 153.93 square kilometers. In general, the city of Tangerang is at 14 meters above sea level. The maximum rainfall occurs in February which is $396 \mathrm{~mm}$, with average humidity and temperature of 80 percent and $24.2{ }^{\circ} \mathrm{C}$. The population in the city of Tangerang in 2018 amounted to $2,185,304$. As an area around or buffer the capital of Jakarta and part of Jabodetabek Metropolitan, the population density of Tangerang city is relatively high, which is about 13 people per square kilometer [9].

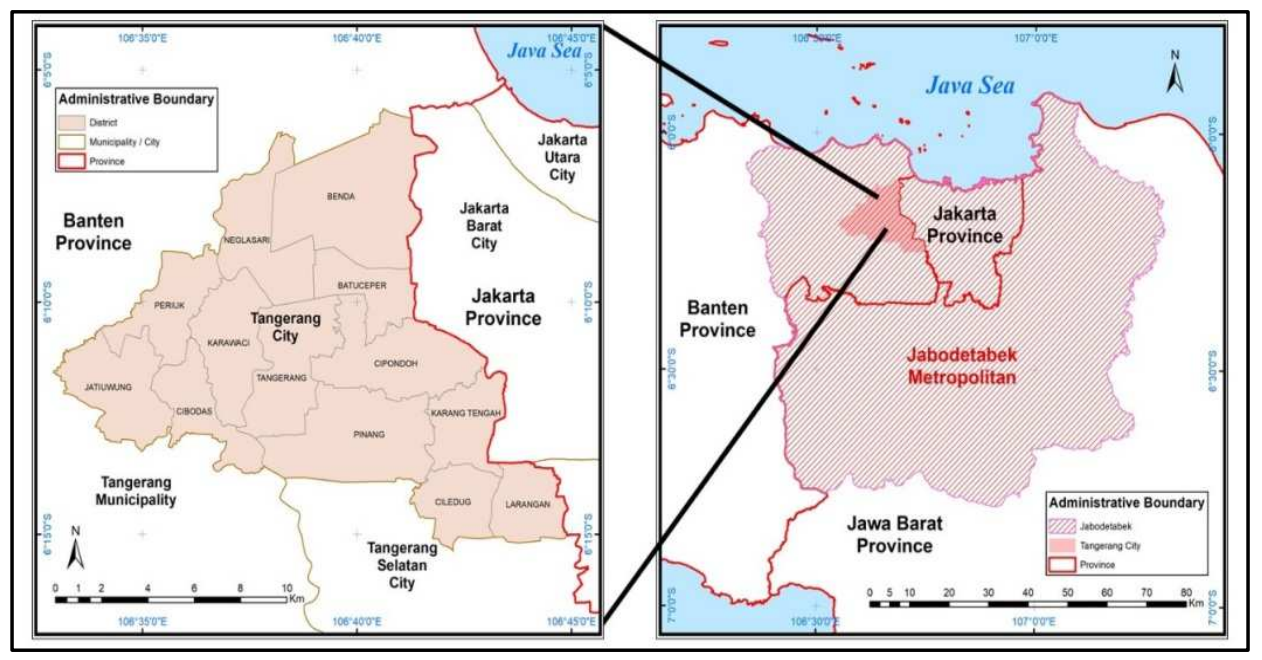

Fig. 1. Map of Tangerang City. 


\subsection{Method}

The concentration value of $\mathrm{CO}$ was obtained from the results of air quality measurement in several locations scattered in each district conducted by the Environment Department of Tangerang City. The amount of data obtained reaches 341 data and it was distributed in 103 locations conducted annually from 2012 to 2018. Some samples were taken at the same location and some were taken at different locations each year.

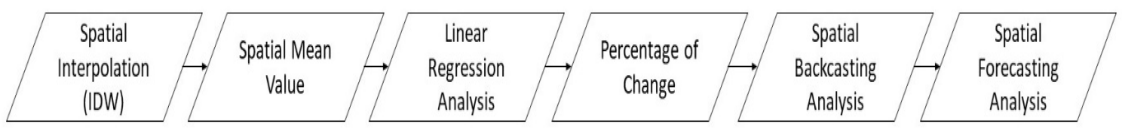

Fig. 2. Research Method.

In general, this research used the Geographic Information Systems (GIS) method. GIS is a computerized system that processes data ranging from data entry phases, data analysis and data presentation designed to problems related to location data and or other georeferenced data [10]. The study was conducted with the following steps: Spatial interpolation method Inverse Distance Weighted (IDW), calculating the Spatial Mean Value, Linear Regression Analysis, calculating Percentage of Change, Spatial Backcasting Analysis, and Spatial Forecasting

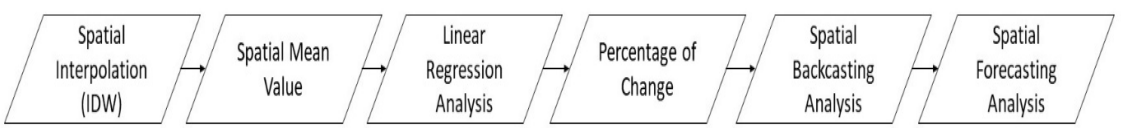

Analysis [

Fig. 2].

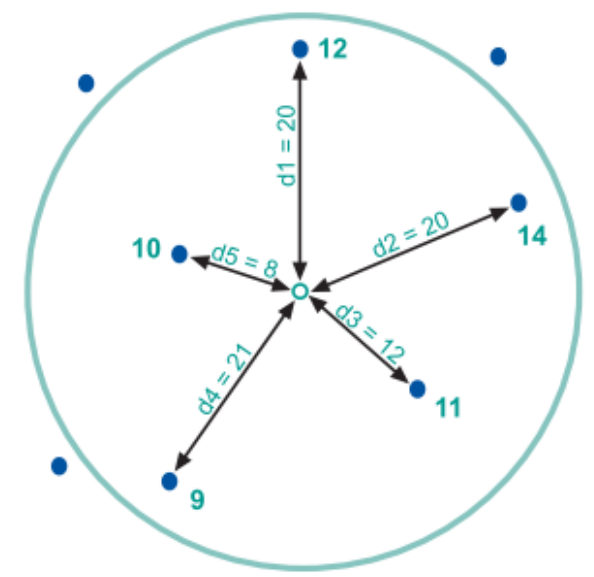

Fig. 3. Spatial interpolation Method Concept IDW [10].

Firstly, CO concentration data in interpolation with the IDW method was used to estimate spatial values based on the value of known points of measurement locations [11]. Spatial 
interpolation (or spatial prediction) aims to predict the values of a target variable located throughout the research area presented in the form of an image or map [12]. This IDW method is a technique to average the value by considering the magnitude of a point around it [Fig. 3]. Spatial interpolation analysis was analyzed with a cell size raster database measuring 30x30 meters, with a total cell of 201.676 cells. Secondly, the interpolated spatial data was calculated spatial average value with the following formula:

$$
\bar{C}=\frac{\sum C_{i} A_{i}}{\sum A_{i}}
$$

Where $\bar{C}, C_{i}, A_{i}$ is spatial mean value $\left(\mu \mathrm{g} / \mathrm{Nm}^{3}\right)$, concentration $\left(\mu \mathrm{g} / \mathrm{Nm}^{3}\right)$, and area $($ cell $)$ With the same CO concentration. Thirdly, spatial mean value data is sorted by year to analyze its linearity. A linear regression analysis was performed to obtain the $R$-Squared $\left(\mathrm{R}^{2}\right)$ value and the best linear formula for Spatial Dynamics analysis. Before being analyzed, data was chosen to reduce the likelihood of errors and improve the accuracy of the research results [13]. The purpose of regression analysis is to get the exact formula against the observed variables, therefore the data on the removal and extreme should be eliminated using the Least Square (LS) method [14]. The concept of the LS method is depicted on [Fig. 4]. Analysis used at least 4 annual data that delivers the largest $R$-Squared $\left(\mathrm{R}^{2}\right)$ value.
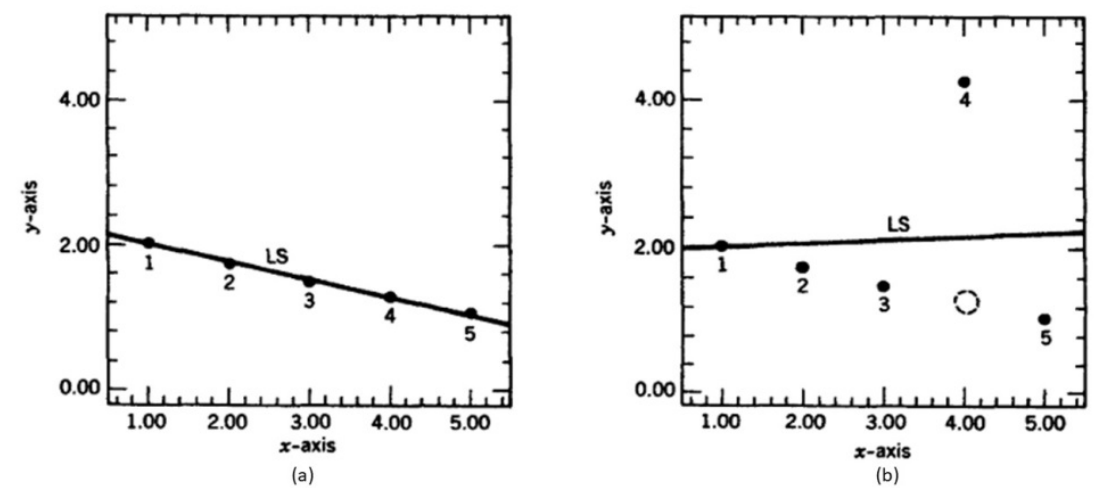

Fig. 4. (a) Original data with five points and their least squares regression line. (b) Same data as in part (a), but with one outlier in the y-direction [14].

Fourth, calculating the value of Percentage of Change based on CO concentration in the early years of linear regression is performed. This percentage value is used to calculate the value of each cell in the backcasting and forecasting methods. Fifth, converting the value of each cell data spatial interpolation in the years used in the analysis becomes an equivalent value as in the first year of linear regression. This analysis was done to get another possibility of the variability of spatial patterns that may occur in the past [15]. Then, all the spatial results of interpolation that have been in Backcasting are averaged the value of each of the cellphones using overlay mathematical raster method. This method facilitates researchers to process the values of each raster grid with mathematical operations on values in other raster data [

Fig. 5]. The spatial pattern formed from the calculation result that is used as the initial spatial pattern for Forecasting analysis. 


$\begin{aligned} & \text { Input 1 } \\
& \begin{array}{|c|c|c|}\hline 1 & 3 & 3 \\
\hline 2 & 2 & 4 \\
\hline 1 & 1 & 3 \\
\hline\end{array}\end{aligned}+$\begin{tabular}{|l|l|l|l|}
\hline 10 & 11 & 11 \\
\hline 10 & 12 & 12 \\
\hline 11 & 14 & 12 \\
\hline
\end{tabular}

\begin{tabular}{|l|l|l|}
\hline 11 & 14 & 14 \\
\hline 12 & 14 & 14 \\
\hline 12 & 15 & 15 \\
\hline
\end{tabular}

Fig. 5. Mathematical Raster Overlay Concept Method [16].

Lastly, perform a Forecasting analysis of cell spatial values into values that may occur in the next few years. The analysis of Forecasting is done with the following formula:

$$
C_{b}=\frac{C_{a}(\%+100)}{100}
$$

Where $C_{b}$ is the concentration of $\mathrm{CO}$ in the predicted year and $\boldsymbol{C}_{\boldsymbol{a}}$ is the concentration of $\mathrm{CO}$ in the year to be foreseen.

\section{Result and Discussion}

\subsection{Result}

Measurement of air quality is done in 13 sub-district and spread in each district with quite variative amount in each year [Table 1]. The most samples were on measurements in year 2016 and the least sample were in the year 2017 and 2018. CO concentration in each of its 


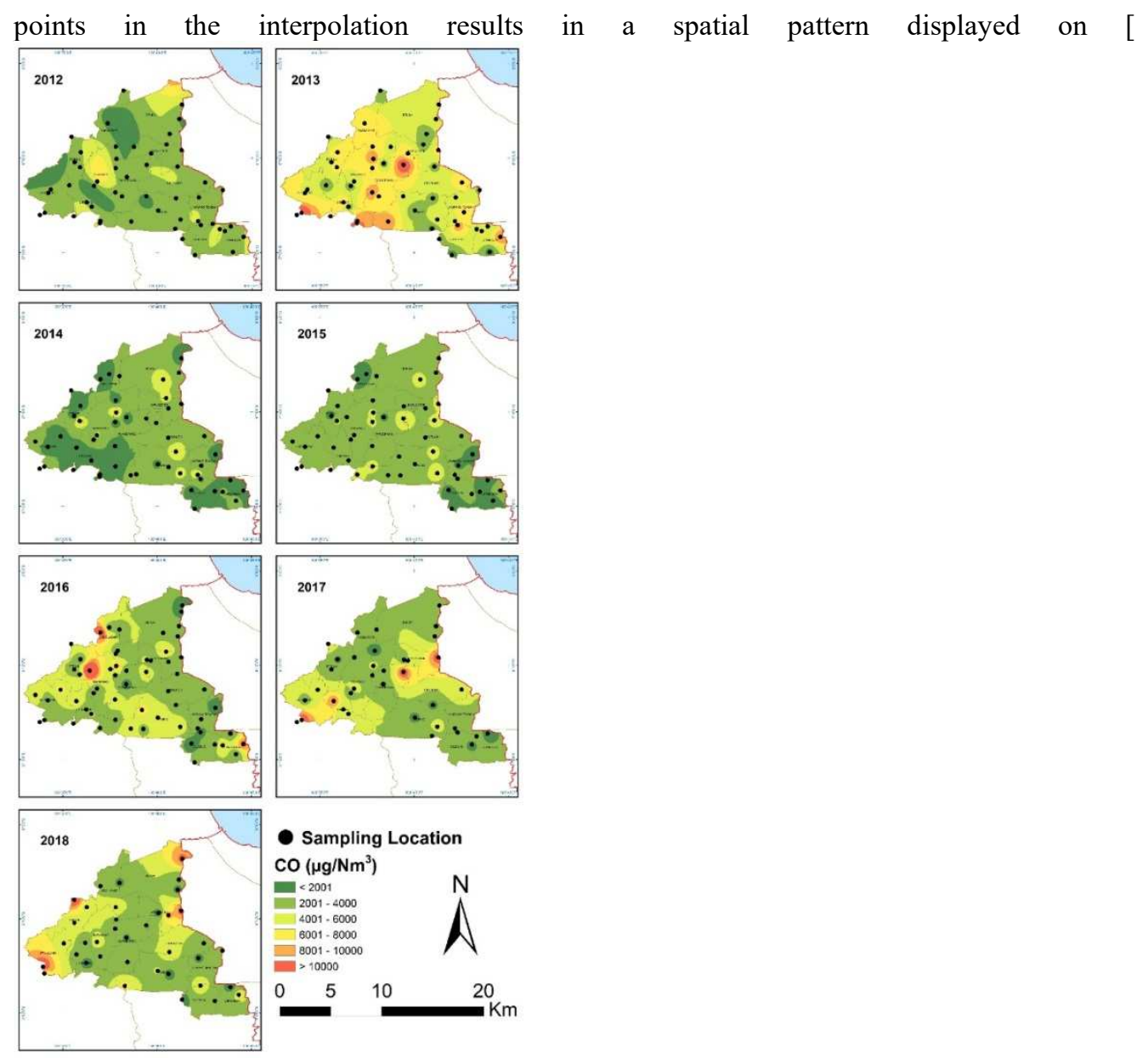

Fig. 7].

Table 1. Number of Air Quality Samples per District

\begin{tabular}{lccccccc}
\hline \multirow{2}{*}{ District } & \multicolumn{7}{c}{ Sample Location } \\
\cline { 2 - 8 } & 2012 & 2013 & 2014 & 2015 & 2016 & 2017 & 2018 \\
\hline Ciledug & 4 & 4 & 4 & 4 & 4 & 3 & 3 \\
Larangan & 4 & 4 & 4 & 4 & 4 & 1 & 2 \\
Karang Tengah & 4 & 4 & 4 & 4 & 4 & 2 & 2 \\
Cipondoh & 4 & 4 & 4 & 4 & 4 & 2 & 3 \\
Pinang & 5 & 5 & 5 & 5 & 5 & 3 & 3 \\
Tangerang & 4 & 4 & 4 & 4 & 5 & 3 & 3 \\
Karawaci & 3 & 3 & 3 & 4 & 5 & 3 & 3 \\
Jatiuwung & 5 & 5 & 5 & 5 & 5 & 4 & 3 \\
Cibodas & 5 & 5 & 5 & 4 & 5 & 3 & 3 \\
Periuk & 4 & 4 & 4 & 4 & 4 & 4 & 3 \\
Batuceper & 3 & 3 & 3 & 3 & 5 & 3 & 3 \\
Neglasari & 4 & 4 & 4 & 4 & 5 & 3 & 3
\end{tabular}




\begin{tabular}{lccccccc} 
Benda & 3 & 3 & 3 & 3 & 5 & 3 & 3 \\
\hline Total & 52 & 52 & 52 & 52 & 60 & 37 & 37 \\
\hline
\end{tabular}

Spatial interpolation results are classified into 6 classes, thus forming patterns with magnitudes that can be clearly visible in difference. The highest classification $(>10.000$ $\mu \mathrm{g} / \mathrm{nm} 3 \mathrm{hr}$ ) is determined based on the maximum limitation of ambient air quality in Indonesia [7]. The more reddish-coloured indicates the higher concentration of $\mathrm{CO}$, and conversely increasingly greenish indicates the lower concentration of $\mathrm{CO}$.

The CO concentration size is averaged based on the number of cells with the same concentration using the formula (1). Data Spatial Mean Value is sorted by year and presented as in [Table 2]. Then, created a graph depicting the linearity of the concentration $\mathrm{CO}$, wherein the year on $\mathrm{X}$ axis and $\mathrm{CO}$ concentration on the $\mathrm{y}$ axis of the chart.

Table 2. Spatial Mean Value, R-Squared, and Linear Regression Equation

\begin{tabular}{c|ccccccc|c|c}
\hline Year & 2012 & 2013 & 2014 & 2015 & 2016 & 2017 & 2018 & $\mathrm{R}^{2}$ & $\begin{array}{c}\text { Linear } \\
\text { Regression } \\
\text { Equation }\end{array}$ \\
\hline $\begin{array}{c}\mathrm{CO} \\
\left(\mu \mathrm{g} / \mathrm{Nm}^{3}\right)\end{array}$ & $3142 *$ & $5883 *$ & 2532 & 2983 & $4011 *$ & 3920 & 3973 & 0.9614 & $\begin{array}{c}381.89 \mathrm{x}- \\
766536\end{array}$ \\
\hline
\end{tabular}

The plotted data, in the best $\mathrm{R}^{2}$ value test by eliminating some data until it remains at least 4 data. The analysis showed that the best $\mathrm{R}^{2}$ data was obtained by eliminating the data of 2012, 2013, and 2016 [Fig. 6]. Based on the data used (data in 2014, 2015, 2017, and 2018) are obtained $\mathrm{R}^{2}$ values of 0.9614 . This implies that the model variables provide $96.14 \%$ and another $3.86 \%$ significant level caused by other variables unexplained on the model.

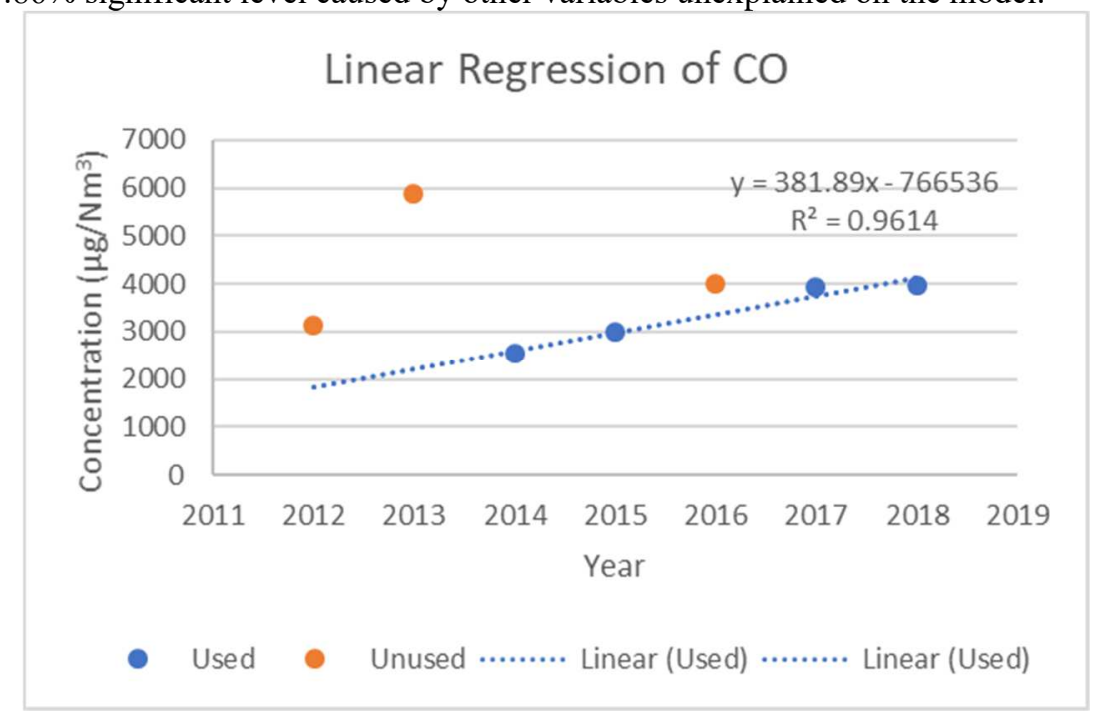

Fig. 6. Linear Regression Graph of CO.

The regression formed a quadratic equation of the $y=381.89 \mathrm{x}-766536$, which is used to calculate the prediction of CO concentration [Table 3]. Year 2014 is the first year in this 
spatial dynamics model, therefore the value of the percentage is also worth 0 . The percentage value in the following years is calculated by the formula (2). Based on the average tabulation value on [Table 3], the $\mathrm{CO}$ concentration passes the quality standard of air quality in Indonesia in 2034 .

Table 3. Concentration and Percentage of CO (Prediction)

\begin{tabular}{ccc|ccc}
\hline \multirow{2}{*}{ Year } & \multicolumn{3}{c}{ CO } & \multirow{2}{*}{ Year } & \multicolumn{2}{c}{ CO } \\
\cline { 2 - 3 } \cline { 5 - 6 } & $\mu \mathrm{g} / \mathrm{Nm}^{3}$ & $\%$ & & $\mu \mathrm{g} / \mathrm{Nm}^{3}$ & $\%$ \\
\hline 2014 & 2532 & 0 & 2027 & 7555 & $198.43 \%$ \\
2015 & 2983 & $17.85 \%$ & 2028 & 7937 & $213.52 \%$ \\
2016 & - & - & 2029 & 8319 & $228.61 \%$ \\
2017 & 3920 & $54.85 \%$ & 2030 & 8701 & $243.69 \%$ \\
2018 & 3973 & $56.93 \%$ & 2031 & 9083 & $258.78 \%$ \\
2019 & 4500 & $77.75 \%$ & 2032 & 9464 & $273.86 \%$ \\
2020 & 4882 & $92.84 \%$ & 2033 & 9846 & $288.95 \%$ \\
2021 & 5264 & $107.92 \%$ & 2034 & 10228 & $304.03 \%$ \\
2022 & 5646 & $123.01 \%$ & 2035 & 10610 & $319.12 \%$ \\
2023 & 6027 & $138.09 \%$ & 2036 & 10992 & $334.20 \%$ \\
2024 & 6409 & $153.18 \%$ & 2037 & 11374 & $349.29 \%$ \\
2025 & 6791 & $168.26 \%$ & 2038 & 11756 & $364.37 \%$ \\
2026 & 7173 & $183.35 \%$ & 2039 & 12138 & $379.46 \%$ \\
\hline
\end{tabular}



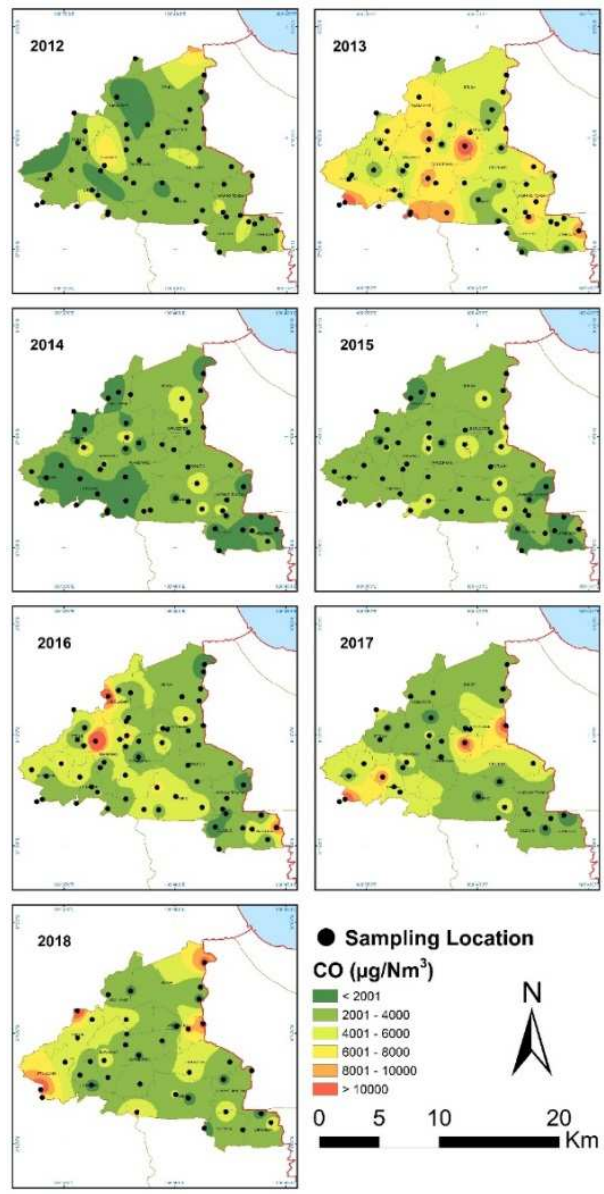

Fig. 7. Map of Air Quality Sample Location.

Although the predicted value of average concentration is known to exceed the quality of air standards in the year 2034, but not necessarily in all areas of the city of Tangerang affected by the same phenomenon. Therefore, spatial analysis is done by processing a description of the spatial patterns that have been known to the formation. All that is needed is only the pattern, then the values of the concentration in each cell are equated with the value in the initial year of regression (year 2014) with the backcasting method using the formula (3). Spatial patterns in known for CO concentrations (year 2015, 2017, and 2018) are depicted in [Fig. 8].

Because the nature of air physics is very possible to change in a short time, then the backcasting spatial pattern is considered as a possible spatial patterns of air pollution that occurred in the year 2014. The patterns are averaged by each cell, thus forming a pattern such as the [Fig. 9 (a)]. The pattern was used as a reference to form the prediction of the $\mathrm{CO}$ air spatial pollution pattern in the future.

In [Table 3] It is known that the year 2034 is predicted to have a spatial average value that passes through the standard of air quality, hence the spatial pattern is predicted by the formula (4) so as to form a spatial pattern on [Fig. 9 (c)]. The pattern in predictions is formed in 16 
years after the known variable end data, then to support the results of these predictions, spatial patterns in the middle year ( 8 years) also being analyzed to form a spatial pattern on [Fig. 9 (d)].

Spatial Data is converted into table Form presented on [Table 4]. It is known that the district area that is sufficiently maintained the quality of its environment is prohibited district (marked by green in the table). It is based on the results of spatial predictions that resulted in the conclusion that the district prohibition has not touched the quality of air standards to $\mathrm{CO}$ until 2034. Conversely, the district whose air quality is expected to be bad, namely Cipondoh, Jatiuwung, and Batuceper sub-districts (marked in red in the table). The area is even estimated about $90 \%$ of its area has passed the quality standards of air to CO in the year 2034 . These findings may be a further consideration for local governments, as well as to make the trigger for further and in-depth research.
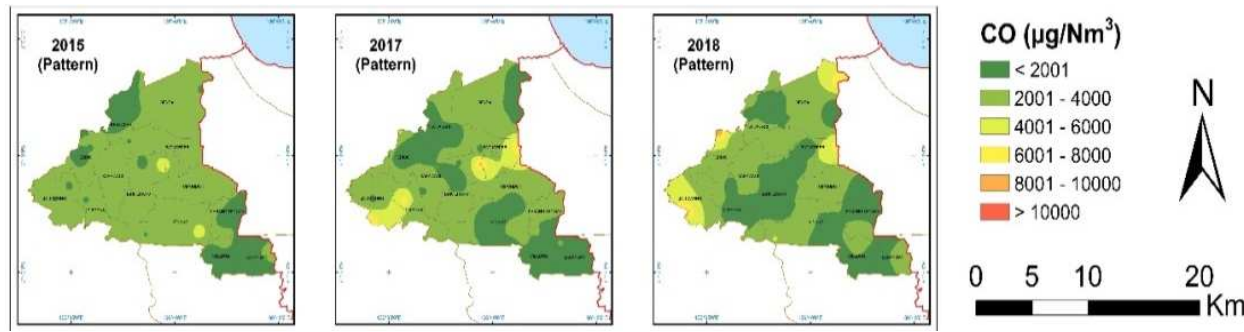

Fig. 8. Spatial pattern with backcasting values in 2014.

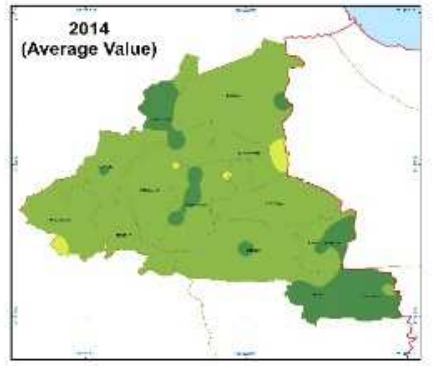

(a)

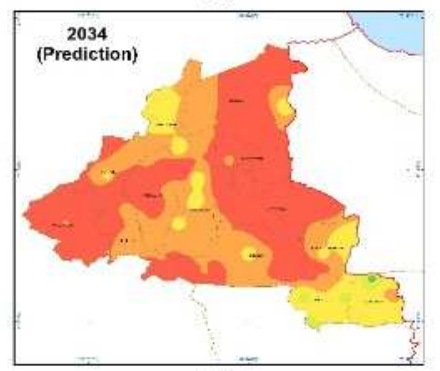

(c)

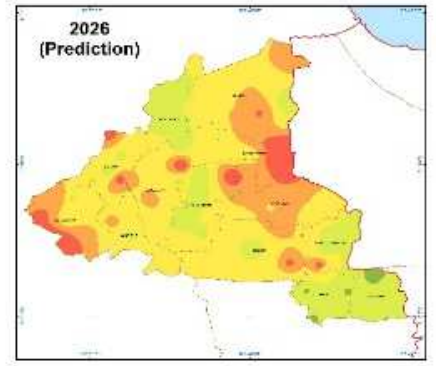

(b)

$\mathrm{CO}\left(\mu \mathrm{g} / \mathrm{Nm}^{3}\right)$

표 2001

II $2001-1000$

$4001-6000$

$\square 001-8000$

$8001-10000$

i. $>10000$

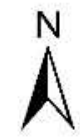

$\begin{array}{llll}0 & 5 & 10 & 20\end{array}$

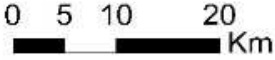

Fig. 9. (a) Spatial pattern of CO with average value in year 2014, (b) Prediction of spatial pattern of $\mathrm{CO}$ in mid-year before passing quality standard (8 years after regression), (c) Predictions of spatial pattern of the $\mathrm{CO}$ in average spatial value passed quality standard (16 years after regression). 


\subsection{Discussion}

The usage of IDW spatial methods for air quality analysis has been carried out by several studies $[17,18]$. However, these studies did not include elements of the back-casting method in them. Whereas the concentration of air quality always changes depending on the time and weather that occurs [19]. Therefore, this study incorporates a back-casting method to estimate the prediction of air quality conditions based on measurement data from several years.

This research discusses only variable $\mathrm{CO}$ concentrations representing air pollution occurring in Tangerang City, then research for variables and other locations should be done to test the accuracy and precision of this method. This research should continue with the value of the graph of statistical methods and other predictions as well, as an example with the system dynamics method. Other variables of air quality support should also be considered, such as population density, land use, congestion, etc.

\section{Conclusion}

This research results in predictions and forms a spatial pattern that may occur in the future. The air pollution $\mathrm{CO}$ in Tangerang City is expected to exceed the quality of air standards in year 2034. It should be a serious concern for the community and local government of Tangerang City. Control of air quality (especially CO) can be started, such as reforestation, restrictions on the use of private vehicles, limiting industries that produce high pollution, and so on, to maintain the sustainability of life.

\section{References}

[1] M. Li and L. Mallat, "Health Impacts of Air Pollution," SCOR The Art \& Science of Risk, no. July, pp. 1-29, 2018.

[2] US Department of Health and Human Services, "Rural and Urban Differences in Air Quality , 2008 - 2012 , and Community Drinking Water Quality , 2010 - 2015 - United States," Morb. Mortal. Wkly. Rep., vol. 66, no. 13, 2017.

[3] H. Mayer, “Air pollution in cities," Atmos. Environ., vol. 33, no. 24-25, pp. 4029-4037, 1999.

[4] J. H. Leem, S. T. Kim, and H. C. Kim, "Public-health impact of outdoor air pollution for 2nd air pollution management policy in Seoul metropolitan area, Korea," Ann. Occup. Environ. Med., vol. 27 , no. 1, pp. 3-11, 2015.

[5] S. Z. Ilyas, A. I. Khattak, S. M. Nasir, T. Qurashi, and T. Durrani, "Air pollution assessment in urban areas and its impact on human health in the city of Quetta, Pakistan," Clean Technol. Environ. Policy, vol. 12, no. 3, pp. 291-299, 2010.

[6] D. Bael and J. Sample, Life and breath: How air pollution affects public health in Twin Cities. Minnesota: Minnesota Department of Health, 2015.

[7] Peraturan Pemerintah Republik Indonesia Nomor 41 Tahun 1999. 1999.

[8] G. T. Goldman, M. J. Strickland, M. Klein, L. A. Waller, P. E. Tolbert, and E. S. Edgerton, "Ambient Air Pollutant Measurement Error: Characterization and Impacts in a Time-Series Epidemiologic Study in Atlanta," Environ. Sci. Technol., vol. 44, no. 19, pp. 7692-7698, 2010.

[9] BPS, Kota Tangerang dalam Angka 2019. Tangerang: BPS-Statistics of Tangerang City, 2019.

[10] R. A. de By et al., Principles of Geographic Information Systems. Enschede, The Netherlands: The International Institute for Aerospace Survey and Earth Sciences (ITC), 2001.

[11] Q. Liang, S. Nittel, J. C. Whittier, and S. de Bruin, "Real-time inverse distance weighting interpolation for streaming sensor data," Trans. GIS, vol. 22, no. 5, pp. 1179-1204, 2018. 
[12] T. Hengl, A Practical Guide to Geostastical Mapping, vol. 13, no. 6. Luxembourg: Office for Official Publications of the European Communities, 2009.

[13] K. A. Barchard and Y. Verenikina, "Improving data accuracy: Selecting the best data checking technique," Comput. Human Behav., vol. 29, no. 5, pp. 1917-1922, 2013.

[14] P. J. Rousseeuw and A. M. Leroy, Robust Regression And Outlier Detection, 1st ed. Brussels, Belgium: John Wiley \& Sons, 1987.

[15] K. H. Dreborg, "Essence of backcasting," Futures, vol. 28, no. 9, pp. 813-828, 1996.

[16] J. Campbell and M. Shin, Essentials to Geographic Information Systems. Irvington, NY: Flat World Knowledge, Inc.

[17] L. O. Rivera-González et al., "An assessment of air pollutant exposure methods in Mexico City, Mexico," J. Air Waste Manag. Assoc., vol. 65, no. 5, pp. 581-591, 2015.

[18] H. J. Jumaah, M. H. Ameen, B. Kalantar, H. M. Rizeei, and S. J. Jumaah, "Air quality index prediction using IDW geostatistical technique and OLS-based GIS technique in Kuala Lumpur, Malaysia," Geomatics, Nat. Hazards Risk, vol. 10, no. 1, pp. 2185-2199, 2019.

[19] M. Cetin, H. Sevik, and K. Isinkaralar, "Changes in the particulate matter and CO2 concentrations based on the time and weather conditions: The case of Kastamonu," Oxid. Commun., vol. 40, no. 1-II, pp. 477-485, 2017. 


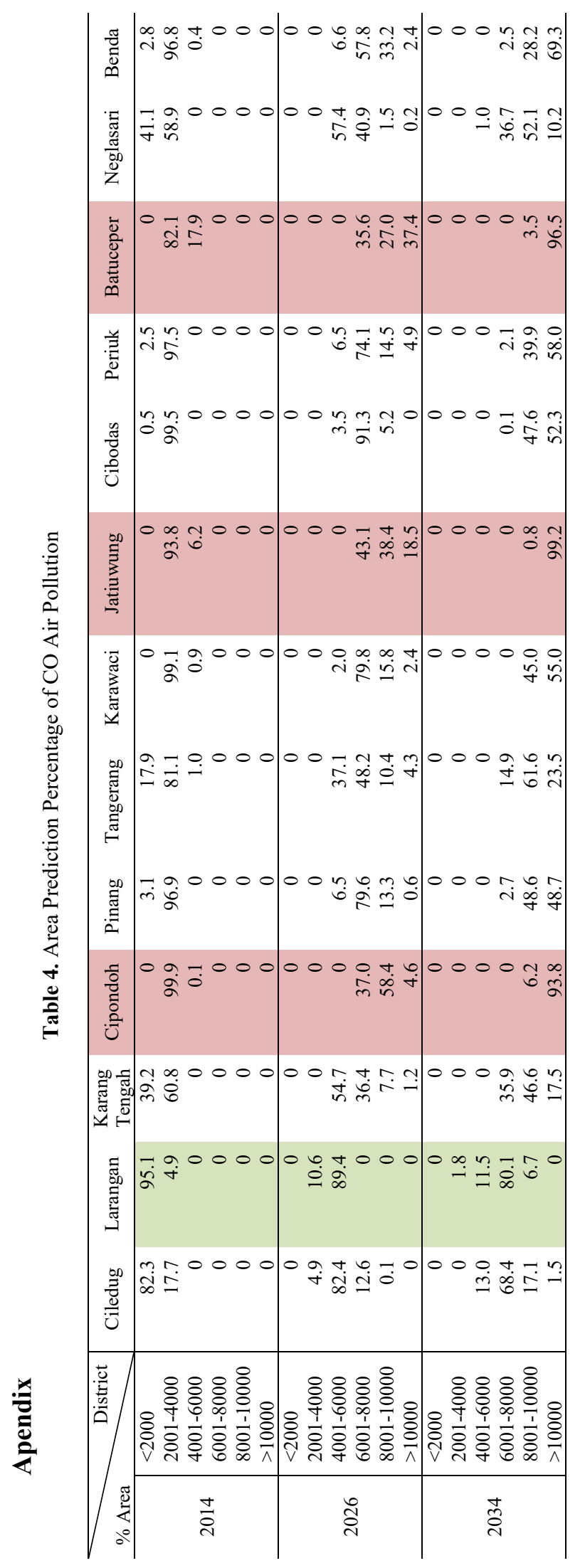

